\title{
SEXUAL VIOLENCE AGAINST WOMEN IN DRC: UNDERSTANDING THE MOTIVATIONS OF A CRIME AGAINST HUMANITY
}

\author{
Dr. iur. Ambroise Bulambo (J.D)*
}

\begin{abstract}
The crimes perpetrated in DRC are supported by diverse evidence. However, no one has up to now sought to explain in a systematic way the motivations of those perpetrators for such violence against women. My paper offers five hypotheses. According to several sources, the acts of sexual violence in the armed conflicts in the DRC were motivated by racist and/or sexist impulses (Section 1); They were used either to submit an ethnic group, a national or ideological opponent (Section 2), or to exterminate or destroy a national or ethnic group deemed inferior (Section 3). They were also used either as a weapon of war to intimidate civilians population under attack (Section 4), or as a medical treatment against HIV/AIDS (Section 5). In this paper, the author tries to explain these motivations.
\end{abstract}

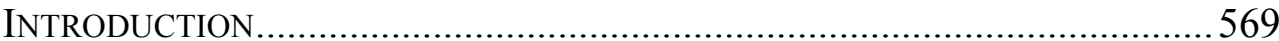

I. CRiminal ACts Motivated By Racist and/OR SEXISTS IMPUlSES......570 II. A WEAPON OF WAR TO SUBMIT AN ETHNIC GROUP, A NATIONAL, OR IDEOLOGICAL OPPONENT .................................................................5.572 III. A WeApon of WAR to Intimidate the Civilian Population Under

IV. A WEAPON OF WAR TO EXTERMINATE OR DESTROY, IN WHOLE OR IN

PART, A PROTECTED GROUP 573

V. SeXual Constraints For Medical TREATMEnT AGAInst HIV/AIDS

CONCLUSION 575

\section{INTRODUCTION}

Sexual violence is a common characteristic of the armed conflicts that have taken place in the Democratic Republic of the Congo (DRC). In DRC, sexual abuse of extreme gravity continues to be committed by armed groups, both state and non-state actors, by blue helmets and civilians in eastern

\footnotetext{
${ }^{*}$ He is Professor of Law at Université Catholique du Congo, Kinshasa (DRC), researcher at faculty of Law (University of Fribourg). Research fields: Constitutional Law; Labor Law, Freedom of Expression, Studies of the Genocide, the Social Responsibilities of the Transnational Companies, the Rights of the Women, the Rights of the Family and the Public Law Generally.

This paper is the finalization of my oral presentation in Encountering Perpetrators of Mass Killings, Political Violence and Genocide, Sep. 1-3, 2015 at University of Wichestester.
} 
Congo $^{1}$. It is estimated that more than six million people have died, and that thousands of women have been raped during the course of this conflict. Rich and diverse evidences have now emerged to corroborate all these crimes. The general consensus is that this evidence is enough to warrant their qualification as crimes against humanity. Up to now, however, no one has sought to present, in a systematic manner, the perpetrators' motivations for such violence against women and crimes against humanity. In this paper, we contribute towards the filling of this gap by examining these motivations.

According to several sources ${ }^{2}$, the acts of sexual violence in the armed conflicts in the DRC were motivated by racist and/or sexist impulses (Section 1); They were used either to submit an ethnic group, a national or ideological opponent (Section 2), or to exterminate or destroy a national or ethnic group deemed inferior (Section 3). They were also used either as a weapon of war to intimidate civilians population under attack (Section 4), or as a for medical treatment against HIV/AIDS (Section 5).

\section{CRIMINAl ACts Motivated By Racist AND/OR SEXISTS IMPUlSES}

Together with Yakin Ertürk, we consider that "The scale and the brutality of sexual violence in DRC seem to have eroded all protective social mechanisms, unleashing brutal fantasies carried out on women's bodies. Civilians are increasingly among the perpetrators of rape, which indicates a normalization of the war-related violence. This intensifies existing inequalities and oppression of women in society. If the sexual violence associated with war is addressed in isolation, gender-based discrimination and violence endured by women in "peace" will be grossly neglected and the war on women reinforced. Women survivors of rape have suffered severe physical and psychological injuries, but lack sufficient care" ${ }^{\prime 3}$. Finally, Basing us on the previous arguments in particular the fact that $90 \%$ the victims report that the perpetrators spoke Kinyarwanda ${ }^{4}$, the fact that Banyarwanda considers the Congoleses as the Bichuchu or the $\mathrm{BMW}^{5}$, the fact that the victims of rapes are mainly women members of the

\footnotetext{
${ }^{1}$ Yakin Ertürk, Report A/HRC/7/6/Add. 4 of the Special Rapporteur on Violence against Women, Its Causes and Consequences, Mission to the Democratic Republic of the Congo, $\S 13,19,25,30-33$, 38, 47-54 (Feb. 28, 2008).

${ }^{2}$ Many authors, UN special Rapporteur, NGO and Testimonies of Victims and Rapists.

${ }^{3}$ Yakin Ertürk, Report A/HRC/7/6/Add.4, § 105-107.

${ }^{4}$ Same opinion, Kataliko Actions for Africa, Report Final for Project TFV/RDC/2007/R2/032 Reconnaissance de l'état de victimes et appui à la réhabilitation psychologique desdites victimes in DRC.

${ }^{5}$ Ambroise Katambu Bulambo, Repression of Revisionism in Congolese Law in Light of Swiss Law, Schulthess Verlag, Zurich 2013, at 158.
} 


\section{SEXUAL VIOLENCE AGAINST WOMEN IN DRC 571}

Congolese ethnic groups well identified and well situated geographically, we can reasonably conclude that the sexual violence acts are motivated by racist and/or sexists impulses.

According to Articles 2 para. 2, 4 and 9 of $\mathrm{CESCR}^{6}$ or s. 11 Let. e of $\mathrm{CEDAW}^{7}$, any discrimination or differential treatment of women because of their female identity or sex is prohibited. These provisions lay down the principle of the prohibition of discrimination against women in the field of social security. According to Swiss Federal Tribunal ${ }^{8}$, a person faces discrimination when that person is treated differently because of his or her membership into a particular group which, historically or in the current social reality, has suffered from exclusion or depreciation. The principle of non-discrimination does not prohibit any distinction based on one of the objective criteria. There must be a special justification ${ }^{9}$. It must be clearly justified $^{10}$. It is difficult to justify any sexual violence perpetrated against the Congolese woman, or any woman belonging to a given ethnic or religious group. Nevertheless, it can be shown that it is based on an unacceptable, prohibited differentiation (viz., the fact that the victim is female and/or belongs to a social group deemed inferior or a religion that must be destroyed) and is therefore a form of unjustified discrimination. Indeed, it can be affirmed that it is based on a differentiation prohibited (belongs to the female gender or to a lower people or to a religion to delete) unacceptable and are of this fact of unjustified discrimination. Prohibited discrimination is in fact a qualified inequality, i.e. a difference of a manifest or particularly shocking treatment, which may have a pejorative connotation. This is the case when women, who are very respected in their ethnic groups and families and regarded as pillars/mothers of the clan, or the ethnic group (as shown by monikers like Na-Balega, i.e., mother of Lega) are raped, sometimes in public, or in front of their children/spouses, or forcefully raped by their children, fathers or even father-in-laws. Here, the woman is depreciated, reduced to an object, to a non-being, to the status of an animal. Men are rarely raped in such conditions. Such a difference in treatment is particularly shocking and has a pejorative connotation.

\footnotetext{
${ }^{6}$ International Covenant on Economic, Social and Cultural Rights International Covenant on Economic, Social and Cultural Rights, RS 0.103.1.

${ }^{7}$ Convention on the Elimination of All Forms of Discrimination against Women Convention on the Elimination of All Forms of Discrimination against Women, RS 0.108.

${ }^{8}$ ATF 137 V 334 S. 347, consid. 6.2.1.

${ }^{9}$ ATF 135 I 49 consid. 4.1.

${ }^{10}$ Idem.
} 


\section{A WEAPON OF WAR TO SUbMit AN ETHNiC GROUP, A NATIONAL, OR IDEOLOGICAL OPPONENT}

In the armed conflicts in the DRC, mass rapes of women are used to submit an ethnic group, a national or ideological opponent. When acting this way, the perpetrators commit a war crime while simultaneously violating several human rights. In debasing women's dignity through sexual coercion, those perpetrators also scare their opponents into submission. It is for this reason that military courts have qualified acts of sexual violence as war crimes. Indeed, it constitutes a serious violation of the laws and customs applicable in international armed conflict as provided by article 8 of the ICC Statute. The case below confirms our previous assertions: Ms Yakin Ertürk reports ${ }^{11}$ some cases which confirm our previous assertions:

In December 2006, a mob of 250 villagers in Karawa $(630 \mathrm{~km}$ north east of Mbandaka) reportedly attacked a police station and lynched a man held at the station whom the villagers accused of witchcraft. In response, PNC assembled about 70 police officers from other duty stations (Businga, Bobadi and Inera) and pillaged Karawa and raped at least 30 women, including a pregnant woman and four minor girls.

\section{A WEAPON OF WAR TO INTIMIDATE THE CIVILIAN POPULATION UNDER ATTACK}

In the armed conflicts in the DRC, mass rapes of women are often committed in the context of a widespread or systematic attack against civilians in order to intimidate, or instill fear in, the populace. Because of this, rape is also considered as a crime against humanity (art. 7 Statutes ICC). This is the case of Kasika in 1998, where in the course of a generalized attack against civilians and three nuns of the Roman Catholic mission at Kasika (Province of Sud-Kivu) were raped before being murdered by the rebel troops of RCD/APR of Rwanda. Others cases reported by Ms Yakin Ertürk ${ }^{12}$ confirm our opinion:

In March 2006, a local mob in Lifumba Waka $(515 \mathrm{~km}$ north east of Mbandaka) took the local PNC Commander hostage to protest against police abuses. Policemen from Basankusu police station reportedly responded with an indiscriminate reprisal against the entire civilian population. Thirty seven women were raped, including three minors and two pregnant women.

In August 2006, several tax collectors were violently attacked in Bolongo Loka (512 km north east of Mbandaka). Police from Botewa Police Station

\footnotetext{
${ }^{11}$ Yakin Ertürk, Report A/HRC/7/6/Add.4, §34-35 and 39.

${ }^{12}$ Yakin Ertürk, op. cit., §42-45.
} 


\section{SEXUAL VIOLENCE AGAINST WOMEN IN DRC 573}

reportedly organized indiscriminate reprisals against the civilian population and raped at least 60 women, including 1 pregnant woman.

\section{A WEAPON OF WAR to EXTERMINATE OR DeSTROY, IN WHOLE OR IN PART, A PROTECTED GROUP}

When carried out to exterminate or destroy, in whole or in part, a national, ethnic, racial or religious group, rape constitutes a crime of genocide, as provided for by article 6 of the Rome Statute. Through sexual coercion, often accompanied by acts of inhumane, cruel and degrading treatment, there is serious harm to the physical or mental integrity of women, or members of a targeted group (art. II, let. b Convention against genocide and 6 ICC Statute). Worth emphasizing here is the fact that several perpetrators of sexual violence are either FDLR combatants or Rwandan Rasta, some of whom have reportedly been implicated in the genocide in Rwanda $^{13}$. In fact, the acts of sexual violence perpetrated in the East of the DRC are reminiscent of those perpetrated by the interahamwe militia during the Rwanda genocide. Here, the FDLR combatants raped women belongs to a national group (Congolese regarded as bichuchu $=$ shadow of a person) ${ }^{14}$. In doing so, these combatants attacked groups which are distinguished as such self-identification or groups recognized as such by others, including the authors of crimes (identification by a third party), and which those combatants seek to destroy the woman as mother of the family, the clan, and the ethnic group. The objective sought by the FDLR combatants is therefore the physical and psychological destruction of women. This has implications on the society as a whole. Women were gang raped, often in front of members of their family and community. In many cases, men were forced, under the threat of arms, to have sexual relations with female members of their own family (their own daughters, mothers, or sisters). It also happens that women received gun shots or were stabbed in the vagina after having been raped. At times, the perpetrators of these crimes required some women in captivity to eat excrement or the flesh of their murdered relatives. These criminal acts were also carried out by other armed groups ${ }^{15}$. In several cases, in fact, the rapists imposed sexual acts on women regarded as representatives of an ethnic or religious group, or distinctive national group, recognized as such by others, and the rape perpetrators. The following cases are illustrative.

\footnotetext{
${ }^{13}$ Yakin Ertürk, Report A/HRC/7/6/Add.4, §2 and 21.

${ }^{14}$ Ambroise Katambu Bulambo, op. cit., at 158.

${ }^{15}$ Yakin Ertürk, op. cit., \$2 and 17-25.
} 
In her Report, Ms. Iulia Motoc reports that:

Many of the victims (members of identified ethnic groups) treated at hospitals in the provinces of Kivu are between 10 and 14 years old and some 40 per cent of them are seropositive ${ }^{16}$.

In her report, Ms Yakin Ertürk ${ }^{17}$ asserts what follows:

In some cases, the perpetrators deliberately seek to destroy the victim's genital and reproductive organs. The perpetrators rammed a stick into her vagina, damaging her genital organs". She estimates that " 20 per cent of all rape victims in Sud-Kivu have suffered irreparable damage to their genital organs. Many rape victims also suffer vaginal fistula, i.e. the tearing of a hole (fistula) in the tissue between the vagina and the rectum or the vagina and the bladder. A woman suffering from fistula can no longer hold her urine or faeces. The smell is constant and humiliating to the woman. Left untreated, fistula can lead to chronic medical problems, including ulcerations, kidney disease, and nerve damage in the legs. Most fistulas could be treated with a surgical operation. The rapists often infect women with HIV and other sexually transmitted diseases. She estimates "that 22 per cent of rape victims in the province are HIV-positive. Few victims have access to post-exposure prophylaxis, which could significantly reduce the risk of infection, if taken within 24 to 72 hours of the rape.

We conclude that the rapists (HIV/AIDS positive) impose sexual relations as medical treatment against HIV/AIDS. Then all ethnic groups without drugs (ARTV) can be destroyed or exterminated. To the extent that it is used to transmit the HIV virus to women, rape is being used as a biological weapon.

\section{SeXual Constraints For Medical Treatment AGainst HIV/AIDS}

The last motivation for these crimes involves search for cure against HIV/AIDS. According to a local belief, sex with a virgin provides cure against HIV/AIDS.

In her report, Ms Yakin Ertürk reports what follows:

the victims are increasingly young girls. An analysis of the cases in 2007 shows that 13 per cent of the victims are girls younger than 18 years old and that 17 per cent of patients who were treated at the hospital in Bunia for rape related injuries were younger than 12 years $^{18}$.

In her Report, Ms. Iulia Motoc reports ${ }^{19}$ that:

\footnotetext{
${ }^{16}$ Iulia Motoc, Report E/CN.4/2003/43 of April 15, 2003 on the Situation of Human Rights in the Democratic Republic of the Congo, $\S 65$.

${ }^{17}$ Yakin Ertürk, Report A/HRC/7/6/Add.4, §55-58.

${ }^{18}$ Yakin Ertürk, Report A/HRC/7/6/Add.4, § 16 and 18.

${ }^{19}$ Iulia Motoc, op. cit., § 65 .
} 


\section{SEXUAL VIOLENCE AGAINST WOMEN IN DRC 575}

Many of the victims treated at hospitals in province of Kivu are between 10 and 14 years old. Why the rapists persecute the children? The belief that HIV and AIDS can be cured by raping a virgin girl is one myth motivating the rapist ${ }^{20}$.

\section{CONCLUSION}

At the end of this article, we conclude with others authors and testimonies ${ }^{21}$ what follows:

These acts of sexual violence in the armed conflicts in the DRC were motivated by racist and/or sexist impulses; they were used either to submit an ethnic group, a national or ideological opponent, or to exterminate or destroy a national or ethnic group deemed inferior. They were also used either as a weapon of war to intimidate civilians population under attack, or as for medical treatment against HIV/AIDS. As the motivations of the rapists are known, it would now be easy to punish the known persons in charge.

But until now, nobody take the necessary steps to end the widespread impunity. The Women survivors of rape have suffered severe physical and psychological injuries, but lack sufficient care. Without strong international backing, nothing will be done ${ }^{22}$. In particularly, we recommend to the International Criminal Court to investigate war crimes or crimes against humanity-including sexual violence committed after July 1, 2002; Prosecute the responsible of these sexual violence and award compensation to victims and to take appropriate measures to protect witnesses and victims collaborating with the Court. At the same time, we recommend to the international community to support all projects of rehabilitations of victims in DRC. For example, our NGO Kataliko actions for Africa-KAF needs financial support to reinforce and enlarge this clinic to prevent and address sexual and gender-based violence by providing medical and psychosocial care to rural survivors. Without actions combined indeed, the satisfactory results will be difficult to reach ${ }^{23}$.

\footnotetext{
${ }^{20}$ Yakin Ertürk, op. cit., § 16.

${ }^{21}$ More than 300 Women Victims Interviewed by the Organizers of the NGO KAF in Province of Sud-Kivu (DRC).

${ }^{22}$ Yakin Ertürk, op.cit., §101, 106-111.

${ }^{23}$ Haut-Commissaire de l'ONU aux droits de l'homme, Rapport de mars 2011 du Panel à la Haut Commissaire aux Droits de l'Homme sur les moyens de recours et de réparation pour les victimes de violences sexuelles en RDC, Genève 2011, at 63-65/Pablo de Greiff, rapport A/68/345 du 23 août 2013 du Rapporteur spécial sur la promotion de la vérité, de la justice, de la réparation et des garanties de non-répétition, $\S 40-56,62,69,75$.
} 